\title{
A ascese do Banquete e os limites da filosofia
}

The ascent in the Symposium and the limits of philosophy

\author{
Matheus Abreu Pamplona \\ Universidade Federal do Rio de Janeiro (UFRJ) \\ Orcid 0000-0002-8599-0079 \\ matheusjcap@gmail.com
}

Resumo: Neste artigo, apresentarei todos os passos da ascese dialética do Banquete (210a-212b) com o intuito de defender que, ao contrário do que comumente vemos ser defendido pela maior parte dos intérpretes deste diálogo platônico, o télos da scala amoris, ao invés de se constituir como algo plenamente alcançável àqueles que até ali ascenderam, apresenta-se, na verdade, como um limite às capacidades humanas. O filósofo, na leitura por mim adotada, não seria aquele que pacificamente galgou os degraus da ascese dialética e ao fim de seus esforços entrou em contato com a Forma do belo, mas aquele que, precisamente por conhecer os limites de suas capacidades, reconhece até onde pode chegar em sua busca incessante pelo saber.

Palavras-chave: Ascese; Filosofia; Limites.

Abstract: In this paper, I shall present all the steps of the ascent passage in the Symposium (210a-212b) in order to argue that, despite what is sustained by the majority of the interpreters of this platonic dialogue, the telos of the scala amoris, instead of being something completely attainable to those who ascended toward it, presents itself as a limit to human capacities. Thus, the philosopher, in the reading I adopt, would not be the one who calmly climbed the ladder of love and at it's summit 
had intercourse with the Form of beauty, but he/she who, precisely because is well aware of the limits of his/her capacities, is able to recognize how far he/she can reach in his unceasing pursuit of wisdom.

Keywords: Ascent; Philosophy; Limits.

\section{Introdução}

Antes de propriamente apresentar meu comentário à ascese do Banquete (210a-212b), momento derradeiro do elogio de Diotima e parte componente daquilo que ficou conhecido como "mistérios" finais (télea kai epoptiká), contextualizarei rapidamente o discurso de Sócrates e, por conseguinte, procurarei expor de que modo o elogio do filósofo se insere no contexto da sequência de encômios a Erōs.

Antes de qualquer coisa, é importante reconhecer que no elogio de Sócrates vemos ser posto em curso um processo crítico que tem início com a retomada de teses defendidas anteriormente pelos outros simposiastas. Esta retomada, no entanto, antes de se constituir como uma ruptura com tudo aquilo que até então havia sido sustentado por Fedro, Pausânias, Erixímaco, Aristófanes e Agaton, mantém, ou melhor, atualiza, muitas das concepções previamente apresentadas pelos demais oradores $^{1}$, de modo que o Banquete pode ser lido a partir de uma perspectiva que enxerga sob as diferenças próprias a cada um dos elogios um mesmo fio condutor: cada um deles, ainda que à sua maneira, já põe em curso todo aquele processo de revisão do sentido de Erōs, processo que encontra nos elogios de Sócrates e Alcibíades, seu ponto de culminância. Minha tese é que todos os simposiastas, neste sentido, procuram estender o significado do termo "amor" para além da sua conotação sexual originária ${ }^{2}$. Tanto Fedro, quanto Pausânias, Erixímaco,

$1 \quad$ Para uma sumarização de todas as teses sustentadas pelos demais discursantes e que são positivamente retomadas por Sócrates em seu elogio, vide especialmente Sheffield (2006a, p. 37).

2 Sobre o significado de Erōs na Grécia antiga, vide o levantamento feito por Dover (1980, p. 1-2; 1994, p. 67-82) e a discussão presente em Halperin (1985, p. 161-166). 
Aristófanes e Agaton, já associam Erōs a algo outro que um desejo de natureza estritamente apetitiva (sexual), de modo que a unidade do Banquete pode ser fundada exatamente sobre este processo de alargamento semântico.

Se, por questões de economia, não posso aqui demonstrar como isto de fato ocorre, posso, no entanto, rapidamente lembrar que enquanto para Fedro, por exemplo, Erōs atua também como uma força de coesão social ao inspirar em amantes e amados sentimentos de vergonha em relação às coisas vergonhosas e de orgulho ou ambição em relação às coisas belas; sem esses sentimentos, insiste Fedro, não é possível nem ao indivíduo nem à cidade alcançar algo de efetivamente grandioso (178d), para Pausânias, por sua vez, o Amor não é apenas um instrumento pelo qual se tem acesso à vida política da pólis, mas também um princípio que pode efetivamente conduzir à sabedoria e à prática da virtude (184d-e).

Com Erixímaco, por outro lado, esse processo de distensão do significado do amor se maximiza: se anteriormente Erōs era pensado enquanto guia e condutor das ações humanas, agora passa a ser tomado como princípio regulador de todo o kósmos, uma vez que "seu poder se estende a tudo, quer no âmbito do humano quer do divino" (186b) ${ }^{3}$. Quando Aristófanes tomar a palavra veremos ser adotada uma nova perspectiva. Aquela distensão de sentido que mencionei anteriormente dá lugar a uma espécie de retração $0^{4}$ : se no elogio de Eríximaco Erōs assumia a condição de potência cósmica, no discurso de Aristófanes, ao contrário, voltamo-nos exclusivamente para os 3 Para fins de citação do Banquete, utilizo a tradução de José Cavalcante de Souza (2016).

$4 \quad$ Com isto, não pretendo afirmar que Erōs, antes entendido de acordo com Erixímaco sob uma perspectiva de maior universalidade, assume agora, com Aristófanes, uma conotação particular. É uma questão acima de tudo de registro, e não propriamente de quantidade. O suposto sentido particular dado a Erōs por Aristófanes não é, na verdade, menos universal do que o sentido apresentado por Erixímaco. Se o interesse do fisiólogo se voltava para phýsis como um todo, os olhos do dramaturgo, por outro lado, se voltarão a apenas uma parte dela, a phýsis humana. Ao fim do mito contado pelo comediógrafo, perceberemos que ali não se trata mais de discorrer a respeito de uma parte, mas sim também do todo, afinal, é sobre todo o gênero humano que importa realmente falar a respeito. 
limites da phýsis humana. Neste novo contexto o amor torna-se não apenas uma potência anímica, senão que acaba por se confundir com a nossa própria psykhé.

Se Aristófanes havia transformado Erōs em um desejo próprio da alma (192d), desejo que é responsável inclusive por determinar o destino dos seres humanos, afinal, nossa promessa de felicidade futura depende exatamente da possibilidade de satisfação deste desejo, Agaton - ainda que continue tratando Erōs como uma divindade e não como uma afecção propriamente dita, como era o caso de Aristófanes -, ao tornar a alma o local onde Erōs reside (195e), não apenas fará dela a sede das paixões, como também abrirá espaço para pensarmos numa fecundidade que lhe é própria (196e-197a).

Insisto particularmente neste ponto, isto é, na ideia de que todos os elogios contribuem para o processo de rasura daquilo que comumente se acreditaria acerca de Erōs, pois ao fim do Banquete, perceberemos que há um núcleo comum entre o discurso socrático e os outros elogios. Se existem diferenças entre Sócrates e os demais simposiastas, isto também se insere no próprio movimento dialético, de recondução do olhar, no qual a descoberta da unidade depende necessariamente da presença daquilo que é múltiplo. É precisamente este movimento que veremos ser descrito na scala amoris (210a-212b) e que é prefigurado na própria composição dramática do Banquete, a saber, um movimento de descoberta da unidade na multiplicidade.

\section{A ascese do Banquete}

Ao invés de percorrer todo o ensinamento de Diotima, passando em revista um por um dos argumentos por ela defendidos de acordo com a ordem sequencial em que aparecem, lançarei mão de uma estratégia diferente. Minha chave de leitura consiste em tomar o elogio da sacerdotisa como um todo unificado, de modo que a relação que se estabelece entre os "mistérios" finais (210a-212c) e os aqueles primeiros "mistérios" (201d-209e) é uma relação de continuidade. Dito de outro modo, poder-se-ia sustentar que enquanto os primeiros "mistérios" procuram explicar como "amantes" (entendido aqui 
no sentido mais geral do termo, tal como exposto em 205ad) se comportam, os "mistérios" últimos, por sua vez, descreveriam em última instância a atividade de um tipo específico de "amante", o amante do saber. Dito isto, passo diretamente ao segundo estágio do discurso de Diotima para assim indicar quais as consequências epistêmicas que a associação entre a natureza dinâmica de $E r o ̄ s$ e aqueles que filosofam acarreta. Meu objetivo aqui consiste em apontar como no discurso da sacerdotisa a possessão da sabedoria permanece um interdito ao filósofo, pois caso contrário teríamos que lidar com uma possível contradição em relação às premissas por ela estabelecidas quanto à natureza intermediária de Erōs; premissas que, como sabemos, são aceitas pelo próprio Sócrates (201d; 212a).

Passando diretamente à scala amoris, em 210a-211e Diotima descreve uma série de etapas que devem ser cumpridas por aquele que deseja ser iniciado nos "mistérios" últimos de Erōs. Este (i) deve primeiramente dedicar-se ao amor de um único corpo para em seguida gerar belos discursos; ultrapassada esta etapa, (ii) perceberá que a beleza em um corpo é irmã (adelphón) daquela presente em outros corpos, de modo que reconhecerá que a beleza que neles se manifesta é a mesma. Abandonando, pois, o corpo individual do qual se ocupou na primeira etapa de seu percurso, (iii) entenderá que o alvo das suas buscas é o belo que se manifesta na forma (tò ep' eídei kalón), de modo que, a partir de então, passará a devotar o seu amor a todos os belos corpos. É chegado o momento então de (iv) dirigir-se à beleza presente nas almas uma vez que ela se sobreleva à beleza física, para daí mais uma vez gerar belos discursos, lógoi que tornarão melhores os jovens que são o objeto do seu amor. O fato de dedicar-se agora à beleza presente nas almas abrirá caminho para que ele (v) contemple a beleza das leis e das ocupações. Neste ponto, a beleza física quando comparada a formas de beleza cada vez mais abstratas parecerá aos seus olhos como uma beleza de menor importância (smikrón). Das ocupações (vi) passará então aos conhecimentos, onde é chegado o momento de contemplar o belo em toda a sua extensão. Dará neste momento também à luz belos discursos em seu inesgotável amor à sabedoria (philosophiái aphtónōi, literal- 
mente), até que fortalecido e engradecido por estes mesmos discursos, passe da beleza nos conhecimentos ao conhecimento da beleza (tà kalà mathēma). Por fim, (vii) reserva-se ainda aquele que até aqui foi orientado (paidagōgèthēi) a contemplar as coisas belas na sua ordem correta (ephexēs te kaì orthōs) um acontecimento espetacular, o aparecimento súbito (exaíphnēs) do Belo, único, eterno, imperecível. Em "contato" (synóntos) com ele, não mais discursos gerará nem imagens de virtude, mas a virtude verdadeira, uma vez que é "no" verdadeiro que está tocando.

Após esta rápida descrição de todo o itinerário a ser percorrido por aqueles que desejam ser iniciados nos "mistérios" finais, interessa-me discutir como se dá este processo de passagem de um degrau a outro no interior da scala amoris. $\mathrm{O}$ que faz com que o amante não se contente com o objeto do seu amor numa determinada etapa e aspire por sempre mais? Acredito que responder a esta questão nos ajudará a reconhecer tanto a natureza filosófica da ascese, quanto os limites impostos à natureza humana em sua busca pelo saber.

Passando finalmente à ascese, a primeira etapa de todo esse movimento compreende o amor de um único corpo (210a). Diotima aqui é enfática. O dedicar-se primeiramente aos corpos não é meramente uma opção, mas uma necessidade. É necessário (dê̂), insiste a sacerdotisa, que o amante ainda jovem comece pela apreciação da beleza física e, caso seja guiado corretamente, amará primeiramente um único belo corpo para daí gerar belos discursos. Alguns pontos chamam a atenção neste primeiro momento. $\mathrm{O}$ primeiro diz respeito à exigência da presença do belo corpo para pôr em curso todo o movimento descrito na ascese. A resposta mais imediata a isto seria assumir que se trata de algo paradigmático nos diálogos eróticos, porquanto constata algo que é elementar no que diz respeito à natureza humana: o belo inevitavelmente atrai. No Fedro (250b-d), por exemplo, ao contrário da justiça e da temperança, a beleza é descrita como a Forma (eidos) cuja manifestação sensível salta aos olhos de modo mais evidente. Além disto, de um ponto de vista epistemológico, pode-se ainda admitir que é 
a experiência, de uma perspectiva temporal, a origem de todo o conhecimento humano ${ }^{5}$.

Outra resposta, menos óbvia mas que já denuncia todo projeto filosófico que vemos ser desenvolvido na ascese do Banquete, nos é sugerida por Hyland (2008, p. 53) e consiste em assumir que se o conhecimento do belo em si implica na compreensão da beleza em todas as suas dimensões, então parece plenamente pertinente que aí esteja incluída o mais fundamental de todos os modos em que a beleza pode se revelar, i.e., a beleza física.

O segundo ponto sobre o qual gostaria de chamar a atenção diz respeito ao produto gerado neste primeiro degrau da ascese: kaloí lógoi. Lembremos que nos primeiros "mistérios" Diotima havia estabelecido que o érgon de Erōs era a geração e criação no belo (206e) e, antes disso, que todos os seres humanos eram fecundos, tanto no corpo quanto na alma (206c). Isto aponta para uma mudança de perspectiva considerável em relação aquilo que havia sido sustentado anteriormente por Agaton, por exemplo. Se o tragediógrafo fez derivar a criatividade de uma fonte que é, ela própria, externa - "qualquer um em todo caso torna-se poeta, 'mesmo que antes seja estranho às Musas', desde que lhe toque o Amor" (196e) - Diotima, ao contrário, torna a fecundidade um traço característico da nossa própria constituição, tanto corpórea quanto psíquica. $\mathrm{O}$ que anteriormente era descrito como uma atividade divina porque inspirada pelo deus, com Diotima adquire a forma de uma ação que é puramente humana. Este ponto é importante pois nos remete para o que encontramos no elogio de Aristófanes a respeito da distância insuperável que existe entre os planos humano e divino. Se o tornar-se efetivamente igual aos deuses permanece um interdito, mantém-se aberta, no entanto, a possibilidade de se remediar, mesmo que através de um expediente aproximativo, esta natureza deficiente, daí "porque é algo de perpétuo e imortal para um mortal, a geração" (206e). Se Erōs tem em vista também a imortalidade é precisamente porque aspira a superar as limitações que lhe são impostas,

\footnotetext{
A este respeito, vide a distinção operada por Kant $(C R P, \mathrm{~B} 1)$ entre conhecimento puro e empírico na introdução à segunda edição da Crítica da Razão Pura.
} 
ainda que esta potencialidade criativa própria à natureza humana só se desenvolva plenamente a partir do encontro de um meio apropriado para tal, qual seja, aquilo que é belo (206d). No entanto, ainda que este meio a partir do qual a geração é possível deva necessariamente ser, ele próprio, belo, não temos indicação alguma, pelo menos nos "mistérios" iniciais, de que o produto desta fecundidade seja dotado deste mesmo atributo (ainda que, claro, devamos esperar que as obras de Homero, Licurgo e Sólon, utilizadas por Diotima como exemplos de frutos do processo de geração psíquica, sejam consideradas belas). $\mathrm{Na}$ ascese dialética, ao contrário, já no primeiro estágio o próprio produto da geração, os próprios lógoi que nascerão do contato entre amante e amado, são caracterizados como kaloí. Temos aqui, como notou mais uma vez Hyland (2008, p. 54), uma dupla presença da beleza: o belo que atrai o erastếs e a beleza que é gerada a partir desta atração.

Podemos agora nos perguntar o porquê, afinal, desta diferença entre aquilo que vemos ser afirmado na primeira parte do discurso de Diotima e o que é exposto nos últimos "mistérios". Uma boa resposta a esta questão nos é dada por Ferrari (1992, p. 256-7). Sua hipótese consiste em admitir que o que marca distintivamente o amante dos "mistérios" finais é a sua disposição em ser afetado não apenas pela beleza do objeto que atraiu inicialmente o seu olhar, mas principalmente por aquela que provém do seu próprio amor. O que isto significa, afinal? Significa que o efeito que a beleza física provoca neste amante é tão marcante que ele é consequentemente levado a expressar em lógoi todo o seu entusiasmo. Qual seria então o conteúdo deste lógos senão a própria beleza? É exatamente porque estes discursos têm o belo como objeto que o amante pode enfim reconduzir o seu olhar, passando assim de uma etapa a outra da ascese ${ }^{6}$. Neste momento o amante "compreende" (katano-

Dois pontos aqui chamam atenção: em primeiro lugar, note-se que desde as etapas iniciais a ascese é marcada por um caráter fortemente discursivo; em segundo lugar, ao tomar a beleza que o atrai como tópico dos seus discursos, o amante pode finalmente imergir-se completamente no objeto do seu amor. Esta imersão, por conseguinte, implica numa tomada de posição por parte do erastếs, na qual ele procura compreender o que é, afinal, isso que tanto lhe atrai. É esta tentativa de compreensão que faz com que o amante se questione não apenas sobre a beleza do objeto do seu desejo, mas sobre a própria beleza, i.e., sobre o que torna o seu amado belo. 
eîn) então que a beleza do corpo que inicialmente deteve a sua atenção é irmã (adelphón) da beleza que se manifesta em todos os outros corpos (210b). O alargamento do olhar seguido pelo reconhecimento de que, independentemente do exemplar, o belo que neles se instancia é sempre o mesmo, demanda por parte do amante que este seja dotado de uma capacidade "reflexiva". O erastếs, neste ponto, distingue-se de outros amantes precisamente graças a sua demonstrada disposição que possui para pensar filosoficamente, caso contrário, ele sequer teria sido capaz de ser iniciado nos "mistérios" finais. Nesta etapa a scala amoris é tomada por uma verdadeira infusão de "racionalidade"; e os termos utilizados por Platão tanto aqui quanto em outros momentos da ascese (katanoēsai, ennoésanta, kataphronēsanta, theâsthai) corroboram, a princípio, a hipótese de que estes elementos "reflexivos" acompanhariam o amante até o fim de sua jornada7. Que a ascese constitua um processo no qual a "razão" se faz presente, parece-me indiscutível, caso contrário, como poderíamos falar aqui em filosofia?

Antes de avançarmos à próxima etapa da ascese, a que corresponde ao amor das almas, é importante nos perguntarmos se o caráter "racional" da busca erótica implicaria num solapamento dos componentes afetivos que deram início à ascese em primeiro lugar e, consequentemente, numa instrumentalização dos indivíduos que aí se encontram e são o objeto do amor do erastếs, afinal, se o que importa nesta etapa é reconhecer que a beleza de um único corpo é a mesma de qualquer outro corpo belo, torna-se inevitável, ao menos num primeiro momento, que suponhamos que o amante é levado a abandonar de modo definitivo aquele primeiro corpo pelo qual ele se apaixonou e passe então a votar-se indistintamente a múltiplos corpos, como se o que o motivasse agora fosse antes uma espécie de indiferença em relação aos objetos do seu amor do que propriamente uma preferência de ordem individual. Gostaria de passar rapidamente por isto, pois desde a publicação de The individual as an object of love in Plato de Vlastos, acendeu-se um vigoroso debate em torno do possível papel que os indivíduos,

$7 \quad$ Esta característica da ascese é realçada mais uma vez por Hyland (2008, p. 54). 
entendidos enquanto pessoas propriamente ditas, assumiriam no interior da scala amoris. A posição assumida por Vlastos quanto a esta questão é bem conhecida. Partindo de uma definição de amor que é ela própria problemática, porquanto arbitrária, assim penso - Vlastos recorre a uma das definições de philía apresentada por Aristóteles no livro IX da Ética a Nicômaco (1166ba), qual seja, querer o bem de uma pessoa com vistas ao interesse dessa própria pessoa ${ }^{8}$ - e, ao chegar à conclusão de que nem no Banquete, tampouco no Lísis ou na República, vemos ser ensaiado algo que seja sequer próximo daquela definição, este intérprete acredita poder escancarar uma faceta do amor platônico que poucos haviam admitido que existia até então: estaríamos, na verdade, diante de um tipo de amor em que indivíduos seriam tratados apenas instrumentalmente, simplesmente como meios a serem explorados na aquisição daquilo que seria realmente valoroso e que constituiria, no fim de tudo, o verdadeiro objeto de todo o desejo, o belo em si.

Ainda que a posição de Vlastos tenha gerado enorme repercussão, acredito que ela pode ser questionada a partir de várias perspectivas. Em primeiro lugar, tomar pessoas como "imagens" do belo em si não os transforma meramente, como supõe Vlastos, num instrumento nas mãos daquele que deseja ascender até o último degrau da ascese. Ainda que Diotima efetivamente trate indivíduos como instâncias do belo, isto não anula em absoluto a possibilidade de que o erastếs possa realmente amar, desejar, admirar e dedicar-se a qualquer um destes indivíduos ${ }^{9}$. Ora, se já na primeira parte do discurso de Diotima todo dese-

$8 \quad$ Vlastos recorre a Aristóteles pois crê encontrar na filosofia do estagirita um "padrão" com o qual a filosofia platônica pudesse ser comparada, evitando-se assim anacronismos. Curiosamente, o próprio Vlastos (1991, p. 139) reconhece que a definição aristotélica do que seria a philía perfeita é ela própria limitada: "o único amor por pessoas enquanto pessoas que realmente interessa a ele [Aristóteles] é aquele entre membros de uma elite social, em que cada um deles pode dispor de uma afeição desinteressada por seus pares, estando seguro de que normalmente terá a afeição deles em troca”. Ora, esta definição dificilmente responderia às nossas expectativas do que seria o amor. $9 \quad$ É claro que numa cultura sexual fundamentalmente monogâmica como é a nossa, esta hipótese soa absurda. Contudo, a não exclusividade entre parceiros é plenamente compatível com a prática da pederastia na Grécia antiga. Vide a este respeito Brisson (2007, p. 57-61). 
jo é direcionado somente àquilo que é previamente identificado como belo e bom, de modo que não se pode dizer que exista em si mesmo um desejo desprovido de componentes cogniti$\operatorname{vos}^{10}$, parece-me então claro que na scala amoris os objetos que lá estão, se lá estão, é porque são necessariamente reconhecidos como belos pelo erastếs. Por conseguinte, tratar indivíduos como "imagens" da beleza supõe que estes indivíduos sejam identificados como dignos de ser amados em primeiro lugar; é tratá-los como instâncias verdadeiras do belo, como expoentes legítimos daquilo que é realmente valoroso; é considerá-los como atraentes porque dotados de algum valor intrínseco.

Tudo isto se torna mais claro quando lembramos da extensão que o termo kalón assume na Grécia antiga. A este respeito, é excelente a reconstrução feita por Nehamas (2007,

10 De acordo com o mito etiológico contado por Diotima, Erōs em sua busca por beleza, bondade, e sabedoria, oscila entre dois estados: o primeiro, um estado de aporía, herdado diretamente da natureza da mãe, e o segundo, um estado de euporía, adquirido em função da natureza do pai. Contudo, as coisas são mais complexas do que à primeira vista se costuma supor, na medida em que a própria carência de Penia não pode ser tomada como um estado de pura negatividade, uma vez que segundo Diotima, "Pobreza então, tramando (epibouleúousa) em sua falta de recurso engendrar um filho de Recurso, deita-se ao seu lado e pronto concebe o Amor" (203b-c). Ora, se Penia fosse ela própria desprovida absolutamente de recursos, não lhe seria possível tramar e em seguida conceber Erōs. Portanto, esta capacidade de planejar que Erōs possui, não lhe parece advir exclusivamente da natureza paterna. Ora, o que isto significa de um ponto de vista psicológico? Ao despirmos o relato do seu conteúdo mítico, temos que a teoria da motivação que aqui se desenha difere daquelas concepções modernas em que desejo e crença atuam separadamente na ação intencional. Estas teorias operam normalmente com a noção de que toda ação é ativada graças a um desejo não-racional qualquer, de modo que a razão atuaria somente para garantir que os meios para a satisfação deste desejo sejam estabelecidos. Nestas teorias, o desejo, tomado em si mesmo, é desprovido de qualquer atividade deliberativa. Em contrapartida, na perspectiva de Diotima tanto os estados de carência quanto de recurso já pressupõem processos cognitivos e o próprio aspecto deliberativo é ele mesmo desejante. Em termos gerais, poderíamos dizer que no contexto do ensinamento de Diotima o amante deseja somente aquilo que ele identifica antecipadamente como belo e bom, e não o contrário, como se o objeto se tornasse belo porque desejado. Esta última ideia, aliás, é pré-platônica e aparece no fr. 16 de Safo, onde lemos que: "a coisa mais bela é o que quer que se ame" (v. 1-4). Sobre as capacidades cognitivas de Erōs vide Allen (1991, p. 50) e Sheffield (2006b, p. 46-53). 
p. 97-107). A partir primeiramente de uma análise do significado de "belo" na tradição literária grega, este intérprete sustenta que aquilo que denominamos kalón na Grécia antiga não se restringe a uma apreciação de elementos puramente estéticos (como Dover faz parecer), mas implica que permaneçamos atentos também a questões que extrapolam este âmbito, questões que são arraigadas a dimensões sociais complexas e que necessitam ser levadas em consideração caso queiramos compreender por que descrevemos coisas, pessoas, situações e etc. como kaloí e, consequentemente, como dignos de serem louvadas. A conclusão a que Nehamas chega é de que a beleza inevitavelmente atrai. Ora, isto é muito mais do que um truísmo. Dizer que a beleza é essencialmente atrativa é reconhecer que aquilo que se apresenta como belo exige de nós um tipo de resposta que não é apenas avaliativa, mas também afetiva. Não por acaso, o reconhecimento de que algo é belo desperta em nós uma espécie de inquietude; sensação que é amenizada (se é que isso efetivamente é possível) na medida em que procuramos compreender o que é isto, afinal, que nos impacta e nos motiva tanto: o belo, no fim das contas, inspira amor e desejo ${ }^{11}$.

Portanto, se a beleza de um corpo é a mesma daquele presente em outro, nada nos leva a supor que, neste processo de transição, o amante simplesmente abandone aquele que no princípio despertou o seu amor ${ }^{12}$. Nada até aqui sugere algum desprezo da parte do erastés ou uma instrumentalização dos indivíduos. Caso nos mantenhamos atentos ao que Diotima diz, perceberemos que na medida em que o olhar se expande é a intensidade do desejo que a princípio diminui e não propriamente o desejo em si que desaparece. Neste ponto, a letra do Banquete é clara: o que o amante deve desprezar (kataphronésanta) como algo de menor importância (smikròn) não é aquele corpo que primeiramente atraiu a sua atenção, mas o amor excessivo ( $\sigma \varphi o ́ \delta \rho \alpha)$ que o mantinha inicialmente preso a ele (210b). Este relaxamento da paixão permite que o erastếs, ao invés de permanecer restrito a um único amado, possa com$11 \quad$ Vide a nota n. 6.

12 O caso de Sócrates e Alcibíades parece ilustrar bem esta situação, pois mesmo que o filósofo mantivesse uma reconhecida predileção pelo estratego, tampouco ele costumava se privar da companhia de outros jovens. Quanto a isto, vide o próprio testemunho de Alcibíades no Banquete (213b-d e 222b). 
partilhar todo o seu entusiasmo com outros jovens. Ora, isto não deve nos surpreender, afinal uma relação como a que mantinham Agaton e Pausânias era não apenas inabitual como constituía um caso de desvio em relação aquilo que era prescrito pelo nómos pederástico ateniense.

Após este momento em que o foco do erastếs permanece ligado à beleza física, é chegada a hora de reconhecer como a beleza presente nas almas é mais valiosa (timiōteron) do que aquela ligada aos corpos. Como, no entanto, o amante efetivamente perceberia esta diferença qualitativa, não nos é dito. Devemos assumir, contudo, que estamos diante de um princípio da ética socrático-platônica ${ }^{13}$.

Há pouco dizia sobre como o contato com o belo corpo permitiu ao amante gerar discursos cujo tópico era a natureza da própria beleza. Sustentei também que a dupla presença da beleza (a do objeto e a do produto) naquele momento havia despertado no amante uma atitude reflexiva. Inclinado agora a pensar filosoficamente, o erastés passa então, à medida em que seu olhar se expande, a buscar compreender o que tonaria belo o objeto de sua atração. Neste processo de ampliação do entendimento o amante foi levado, partindo inicialmente de um exemplar particular da beleza, a refletir acerca de toda a beleza que se manifesta na forma visível (eídei kalón). É neste momento que o amante, em sua busca por mais inteligibilidade, desloca sua atenção à beleza das almas, que é, de todo modo, a real responsável por tornar os corpos verdadeiramente atrativos. Desta união entre o amante e os jovens cuja beleza das almas ultrapassa a corpórea veremos mais uma vez nascer lógoi. Ainda que não nos seja dito qual a natureza destes discursos, temos, no entanto, um indicativo de sua função: educar, tornar os jovens melhores (210c). É de se supor que neste momento estes lógoi sirvam ao propósito de tornar belas tanto quanto possível as almas daqueles jovens que foram o objeto do seu amor nos estágios

$13 \quad$ No Cármides, ao advogar em favor de uma concepção sinóptica da pessoa, vemos Sócrates afirmar que "é da alma que saem todos os males e todos os bens do corpo e do homem em geral, influindo ela sobre o corpo como a cabeça sobre os olhos. É aquela, por conseguinte, que, antes de tudo, precisamos tratar com muito carinho, se quisermos que a cabeça e todo o corpo fiquem em bom estado" (156e). Para fins de citação do Cármides, utilizo a tradução de Carlos Alberto Nunes (2007). Vide ainda República 403d. 
anteriores. Aqui estamos diante de uma via de mão dupla, na qual amante e amado afetam-se mutuamente ${ }^{14}$.

Indo adiante, da beleza nas almas nos é dito que o erastếs é levado a contemplar a beleza das ocupações e das leis (210c). A passagem a este novo estágio requer por parte do amante um tipo de atividade menos complexa do que aquela necessária na passagem da beleza nos corpos à beleza psíquica. Ainda que neste estágio Diotima empregue mais uma vez um vocabulário que expresse certa atividade "reflexiva" (note-se aqui o uso de theásasthai, por exemplo), nos é dito também que o reconhecimento da beleza nas leis e ofícios segue-se como uma espécie de "obrigação" (anankasthếi) àquele que anteriormente havia contemplado a beleza nas almas. Uma das formas de entender esta prescrição seria admitir que a beleza das leis e ocupações aparecem como uma subespécie da beleza psíquica. A partir do momento que se reconhece isto, a transição entre um e outra segue-se naturalmente, processo pelo qual aquele que pretende compreender o belo em toda a sua amplitude

$14 \quad$ Algumas coisas merecem destaque aqui: em primeiro lugar, se os discursos que neste momento são gerados visam à educação dos jovens, e se estes jovens não são outrem senão aqueles mesmos belos corpos com os quais o amante se relacionou na etapa anterior, então teríamos mais uma evidência, contra a interpretação de Vlastos, de que mesmo que o erastếs desprezasse estes corpos - o que não penso que seja o caso, pois nos é dito que é apenas na etapa subsequente, das ocupações e das leis, que o amante passa a julgar o belo corpo de pouca monta (210c) -, isto não significaria, em absoluto, um desdém por todo o indivíduo, já que parece haver claramente aqui uma preocupação do amante com as almas individuais. Scott (2000, p. 31-5) procura desenvolver esta hipótese recorrendo ao elogio de Alcibíades. Segundo este autor, no elogio do estratego encontraríamos indicativos não apenas de que Sócrates tenha atingindo estágios mais agudos da ascese, mas de que ele, Alcibíades, tenha sido o amado do filósofo num momento específico da jornada daquele, a saber, precisamente o momento em que o amante dirige o seu amor às almas. Recorrendo ao Alcibíades I (131d-e) e ao testemunho de Plutarco, Scott defende que o que Sócrates amava em Alcibíades não era outra coisa senão a sua alma e que toda a sua preocupação dizia respeito à formação do caráter de Alcibíades. De acordo com Scott, estas evidências confirmariam a ideia de que na etapa da beleza das almas, os discursos que ali são gerados visam precipuamente à educação dos amados. Além disso, em 222b o próprio Alcibíades reconhece que ele não era o único amado de Sócrates naquela ocasião, mas também Cármides, Eutidemo e muitos outros, o que sugere, ainda segundo Scott, que a intersubstituição não se restringe à etapa do amor aos belos corpos, e que mesmo quando amante volta sua atenção a estas almas, ele tampouco deixa de prezar pelos indivíduos. 
deve inevitavelmente passar. A hipótese de que os estágios que se seguem ao reconhecimento da beleza nas almas são subespécies desta última, parece-me justificada pela própria letra do Banquete, na medida em que próximo ao fim do seu discurso, Diotima sumariza toda a ascese em apenas algumas etapas:

Eis, com efeito, em que consiste proceder corretamente nos caminhos do amor ou por outro se deixar conduzir: em começar do que aqui é belo e, em vista daquele belo, subir sempre, como que servindo-se de degraus, de um só para dois e de dois para todos os belos corpos, e dos belos corpos para os belos ofícios, e dos ofícios para as belas ciências até que das ciências acabe naquela ciência, que nada mais é senão daquele próprio belo, e conheça enfim o que em si é belo (211c-d).

Notemos que nesta sumarização não há qualquer referência à beleza psíquica como um estágio distinto, de modo que podemos entender que tanto a beleza dos ofícios e dos conhecimentos quanto o conhecimento da própria beleza constituem todas elas exemplares de um tipo de kalón que concerne majoritariamente às almas. Se neste ponto o erastếs é movido por um desejo de compreensão que implica em um conhecimento de ordem etiológica, então é de se esperar que neste momento o amante dirija o seu olhar às leis e aos ofícios precisamente por tomá-las como aquilo que é responsável pela criação das belas almas. Este movimento de redirecionamento do olhar em busca de causas cada vez mais definitivas conduz o amante da beleza dos ofícios à beleza nos conhecimentos. A apreensão da beleza nos conhecimentos permite ao erastếs finalmente contemplar o belo em toda a sua extensão (210d). A imagem é paradigmática e a linguagem utilizada por Diotima para descrever a atitude daquele que aqui chegou remete àquela utilizada por Pausânias na descrição do estado de absoluta servidão a que se sujeita um amante ávido por fazer-se notar perante os olhos do seu amado ${ }^{15}$. Contudo, se o erastếs de Pausânias seria capaz

\footnotetext{
$15 \quad$ Além do amante de Pausânias, o caso de Alcibíades parece se adequar exemplarmente na descrição. Em várias ocasiões, o estratego afirma que perante Sócrates comportava-se tal como um "escravo" (215e, 216b, 219e), submetido a um "jugo" do qual não conseguia escapar; em outros momentos, fala ainda de como se sentia "constrangido" a fazer tudo aquilo que Sócrates lhe "ordenava" (216b, 217a, 218a). Sobre o servilismo de Alcibíades, vide Nightingale (1993, p. 125-6).
} 
de dispor-se "a subserviências a que se não sujeitaria nenhum servo" (183a), o de Diotima, aquele que chega ao estágio de contemplar a beleza dos conhecimentos, o faz, ao contrário,

sem mais amar como um doméstico (oikétēs) a beleza individual de uma criançola, de um homem ou de um só costume, não seja ele, nessa escravidão miserável (douleúōn phaûlos), e um mesquinho discursador (smikrológos), mas voltado ao vasto oceano do belo e, contemplando-o [...] (210d).

Até aqui vimos que a passagem de um estágio a outro da ascese demanda do erastếs certa capacidade reflexiva: reconhecer características, efetuar comparações, estabelecer relações, classificar, e assim sucessivamente. Todo este processo, no entanto, é bem mais complexo do que normalmente costuma-se reconhecer e envolve não apenas elementos cognitivos, mas também afetivos e criativos ${ }^{16}$.

É a conjunção destes elementos, portanto, que permite ao amante mover-se de um estágio a outro da ascese e alcançar assim um entendimento sinóptico da beleza. A contemplação do "oceano sem fim" do belo é precisamente o momento que an-

16 Moravcsik (1971, p. 288-9) mantém-se atento a este estado de coisas. Ainda que alguns dos pontos por ele discutidos sejam pertinentes, principalmente no que diz respeito ao papel desempenhado pelo noûs em todo a ascese, a interpretação predominantemente "lógica" que propõe não me parece oferecer uma explicação adequada daquilo que realmente está em jogo na jornada proposta por Diotima. Se por um lado Moravcsik reconhece que são os elementos "afetivos" que possibilitam ao amante perfazer o movimento "transcategorial" (processo de passagem entre o estágio que diz respeito especificamente à beleza do corpo àquele que concerne à beleza das almas), por outro, concede a estes mesmos elementos uma função que é caracterizada majoritariamente por uma atitude de menosprezo em relação ao objeto do desejo: o que levaria o amante a buscar novos tipos de beleza seria precisamente os sentimentos negativos que ele mantém em relação às instâncias presentes nas etapas anteriores.

Quanto a este ponto, Moravcsik parece ignorar uma indicação importante do discurso de Diotima, qual seja, a de que o amante reconhece a "menor importância" (lembremos do termo smikrón utilizado pela sacerdotisa em vários momentos) dos objetos presentes nos estágios precedentes somente no momento em que atinge um nível subsequente. Neste sentido, o que o direcionaria este amante ulteriormente na scala amoris não seriam sentimentos propriamente negativos, como "desdém", "desprezo", "rejeição" e etc., mas antes um desejo de compreensão, de imersão total no objeto. Deste modo, Erōs e racionalidade andariam lado a lado, não havendo necessidade de isolá-los tal como quer Moravcsik. 
tecede este entendimento. Ainda que até aqui a tentativa por parte do erastếs de isolar em uma unidade aquilo que é comum a múltiplos objetos tenha se mostrado particularmente promissora - o conteúdo dos lógoi ali produzidos indicam isso -, os efeitos disso no amante, ao invés de satisfazerem plenamente o seu desejo, acabaram por potencializar o que nele residia apenas como uma disposição (lembremos do que Diotima afirmara em 206c-e acerca dos seres humanos serem dotados de fecundidade, tanto física quanto psíquica). Notemos que o simples contato com objeto belo, qualquer que seja ele, não esgota em hipótese alguma o vínculo estabelecido entre o sujeito do amor e o seu objeto. Se assim o fosse, a própria ideia de uma ascese seria desnecessária. Ao invés disso, a imersão do erastếs no objeto belo potencializa o desejo; antes restrito a uma única instância, seu olhar pode enfim expandir-se na medida em que reconhece que o que até então parecera disperso, na verdade permanece intimamente conectado por um profundo grau de parentesco. A subsunção daquilo que é múltiplo a certa unidade permite ao amante mover-se sempre em busca de mais inteligibilidade (busca que, como procurei ressaltar, é predominantemente discursiva).

Podemos agora perceber que esta atividade intelectual de reconhecimento da identidade na diferença atua precisamente em dois níveis: primeiramente no interior de cada estágio, e posteriormente na articulação dos próprios estágios entre $\mathrm{si}^{17}$. Pensemos, por exemplo, no primeiro momento da ascese, referente aos belos corpos. Estes corpos, entendidos enquanto instâncias particulares, devem, a partir da atividade reflexiva do amante, de uma forma ou de outra poder ser incluídos em determinada classe, neste caso a classe da beleza corpórea. Isto é válido para todas as outras instâncias que são objetos nas demais etapas da ascese.

Há pouco fiz referência à inclinação que este amante possui de pensar filosoficamente, e entendo que estes processos reflexivos de descoberta do uno no múltiplo constituem, na verdade, um indicativo desta inclinação. Reconhecido isto, é necessário agora estabelecer em que momento este amante passaria de fato a produzir filosofia; ou seja, quando, afinal,

$\overline{17} \quad$ Vide mais uma vez Moravcsik (1971, p. 287-8). 
esta disposição finalmente se efetivaria. Em minha opinião, a fase de contemplação do "oceano" do belo seria precisamente este momento. Após contemplar o belo em toda a sua extensão, é chegado o momento em que o amante "muitos discursos belos e magníficos ele produza, e reflexões, em inesgotável amor à sabedoria [...]" (philosophíâi aphtónōi (210d). É importante notarmos que este é o único momento de todo o discurso de Diotima em que nos é dito que o conteúdo dos lógoi produzidos é filosófico. O que isto significa? Retomemos o que há pouco eu havia dito a respeito da relação "uno-múltiplo" na ascese. Minha hipótese é de que os lógoi produzidos nas demais etapas, ainda que digam respeito à natureza do objeto belo, não seriam ainda propriamente filosóficos em decorrência da incapacidade do amante de, naquele momento, compreender que a própria classe a que pertence a instância também constitui um "múltiplo", mesmo que, com relação aos objetos particulares, ela assuma a forma de uma "unidade" que, não obstante, é de todo modo ainda parcial. É necessário que um outro tipo de reflexão seja posto em curso pelo amante, qual seja, o reconhecimento de que há algo (o belo que é objeto da ciência) que é causa final e que, portanto, concede unidade às próprias classes (os diferentes tipos de beleza, como a corpórea, a psíquica, a intelectual e etc.). O "oceano sem fim" do belo simboliza justamente este momento em que toda a multiplicidade (as instâncias particulares da beleza e suas respectivas classes) aparece, aos olhos daquele que até aqui chegou, finalmente subsumida a uma unidade que agora é total ${ }^{18}$. Ao adquirir esta compreen$18 \quad$ Com isso, não pretendo sustentar que toda beleza qua beleza é uniforme, tal como faz Nussbaum (2009, p. 156-7). Lembro rapidamente que a perspectiva desta intérprete consiste em admitir que, uma vez que a beleza é sempre a mesma, durante cada etapa da ascese o amante compararia os exemplares em que o belo se instanciaria e reconheceria que eles são plenamente substituíveis entre si, porquanto a beleza que haveria neles diferiria apenas em quantidade. $\mathrm{O}$ resultado disso é que não haveria entre as etapas, no que diz respeito à presença da beleza propriamente, uma diferença de ordem qualitativa.

${ }^{\mathrm{P}}$ or motivos de economia, não posso me debruçar aqui sobre toda a interpretação de Nussbaum, mas acredito que sua posição em favor da uniformidade quantitativa da beleza durante a ascese é injustificável. Em primeiro lugar, ela contém um vício de origem. Nussbaum é levada a assumir que a beleza é uniforme pois confunde, nas premissas estabelecidas no élenkhos, indivíduos particulares com o amor tomado em si mesmo. É este que, presente em nós, faz com que nos tornemos amantes; é Erōs, enquanto desejo, que não pode 
são, o amante "robustecido e crescido, contempla ele uma certa ciência, única, tal que seu objeto é o belo" (210e). É com base nesta possibilidade, do desenvolvimento por parte do erastếs de uma compreensão sinóptica da beleza, que podemos enfim possuir os predicados de que é carente. Sujeitos empíricos, ao contrário, podem muito bem possuir um tipo específico de beleza, ao mesmo tempo em que carecem de outro. Que se trata de realçar a natureza do amor e de despi-lo de qualquer conteúdo empírico, resta claro quando Sócrates, recorrendo a uma analogia, pergunta a Agaton a respeito do irmão se, "enquanto justamente é isso que é, é irmão de algo ou não?" (199e). Ao insistir que o irmão seja definido precisamente enquanto isto mesmo que é (autò toûth' hóper éstin), o objetivo de Sócrates é descartar qualquer possibilidade que se defina "irmão" por algo outro que não aquilo que é próprio à sua natureza. $\mathrm{O}$ mesmo ocorre com Erōs; o que interessa, insiste Sócrates, é delimitar a natureza do amor, estabelecendo quais os objetos que lhe dizem respeito naturalmente.

Em segundo lugar, em 210b lemos que a beleza presente nas almas é mais valiosa (timiōteron) que a do corpo, o que parece implicar numa efetiva distinção qualitativa entre as etapas.

Feito este registro, a pergunta que se impõe é: se há uma diferença qualitativa entre a beleza corpórea e a beleza psíquica, como integrar esta classe de objetos, que parece ser inferior, no "oceano" do belo? Antes de responder a esta questão, reconheço que há de fato uma diferença qualitativa entre estas duas etapas, a da beleza física e a psíquica; a letra do Banquete é clara quanto a isto. Todavia, não penso que há evidências textuais suficientes para assegurar que na etapa do reconhecimento da beleza nas almas, por exemplo, o amante simplesmente abandone aqueles belos corpos, mesmo porque, como afirmei anteriormente, é somente no momento posterior, de contemplação da beleza das ocupações e das leis, que o erastếs julga que aquele belo corpo a partir do qual a própria ascese teve início se torna menos importante (smikrón)(210c). Ora, ainda assim, dizer que algo assume uma importância secundária numa escala de valores não implica, necessariamente, desprezo ou rejeição; acredito que afirmar algo do gênero seria excessivo, de modo que nem mesmo aqui, na etapa das ocupações e das leis, poder-se-ia categoricamente afirmar que o amante abandone aqueles belos corpos. Quanto a isto, recorde-se o que eu havia dito na nota $\mathrm{n} .14$.

Por outro lado, contra a minha leitura poder-se-ia ainda objetar o seguinte: se nesta etapa mais avançada o amante não renuncia aos belos corpos, qual seria então a diferença entre o amor das almas e o amor dos corpos? Acredito que a diferença, da perspectiva do desejo do amante, se explique em termos de causalidade. $\mathrm{O}$ erastếs não é agora movido, necessariamente, pela beleza física apenas; Diotima inclusive afirma que "mesmo se alguém de uma alma gentil tenha todavia um escasso encanto (smikròn ánthos), contente-se ele [o amante], ame e se interesse" (210b-c).

Por fim, mesmo que Diotima conceda que a beleza psíquica é mais valiosa que a beleza corpórea, ambas são semelhantes na medida em que participam da mesma Forma (211b). É isso que faz com que ambos os tipos de beleza sejam integrados no "oceano do belo", momento em que, como procurei demonstrar, tudo aquilo que é múltiplo (e tanto a beleza física quanto a beleza das almas, da perspectiva do belo em si, ainda constituem um múltiplo) finalmente é subsumido a uma unidade. 
interpretar a afirmação de Diotima segundo a qual, é graças à natureza intermediária de Erōs "que o todo (tò pân) fica ligado (syndedésthai) todo ele a si mesmo" (202e). Ainda que seja o noûs o responsável efetivo pelas operações reflexivas que ocorrem na ascese, acredito que estas só são postas em curso em função da presença de uma força que, na verdade, as impulsiona e as conduz. O tò pân a que Diotima se referia talvez não seja outra coisa senão o próprio "oceano" do belo, finalmente integrado a si mesmo.

Contudo, não paramos por aqui. Após o conhecimento do belo, Diotima parece impor ao erastếs a necessidade de que se percorra ainda mais uma etapa, o "intercurso" com o belo em si que se segue ao aparecimento da Forma, este sim o termo da télea kai epoptiká. Segundo a própria sacerdotisa,

Aquele, pois, que até esse ponto tiver sido orientado (paidagōgèthēi) para as coisas do amor, contemplando seguida (ephexēs) e corretamente (orthōs) o que é belo, já chegando ao ápice (télos) dos graus do amor, súbito (exaíphnēs) perceberá (katópsetaî) algo de maravilhosamente belo em sua natureza, aquilo mesmo, ó Sócrates, a que tendiam todas as penas anteriores, primeiramente sempre sendo, sem nascer nem perecer, sem crescer nem decrescer, e depois, não de um jeito belo e de outro feio, nem ora sim ora não, nem quanto a isso belo quanto àquilo feio, nem aqui belo ali feio, como se a uns fosse belo e a outros feio; nem por outro lado aparecer-lhe-á o belo como um rosto ou mãos, nem como nada que o corpo tem consigo, nem como algum discurso ou alguma ciência (oudé tis logos oudé tis epistêmē), nem certamente como a existir em algo mais, como, por exemplo, em animal da terra ou do céu, ou em qualquer outra coisa; ao contrário, aparecer-lhe-á ele mesmo, por si mesmo, consigo mesmo, sendo sempre uniforme, enquanto tudo mais que é belo dele participa, de um modo tal que, enquanto nasce e perece tudo mais que é belo, em nada ele fica maior ou menor, nem nada sofre (210e-211b).

É importante que percebamos que a linguagem empregada por Diotima na descrição da Forma do belo não apenas indica que o último estágio da ascese é qualitativamente distinto do penúltimo ${ }^{19}$, correspondente ao conhecimento da beleza,

$\overline{19} \quad$ Este tipo de ruptura é reconhecido por Chen (1983, p. 69), ainda que seu interesse seja demonstrar que até o momento da contemplação da beleza nos conhecimentos todos os estágios da ascese estão dispostos horizontalmente. Neste caso, a ascese só se tornaria efetivamente uma ascese no momento da transição entre a percepção da beleza na forma de conhecimentos e a apreensão do Belo em si. 
senão que aponta até mesmo para uma espécie de ruptura com relação aos estágios anteriores. Acredito que esta descontinuidade pode ser notada a partir da presença do advérbio exaiphnēs ("subitamente") na descrição do "aparecimento" da Forma. Este ponto é particularmente importante, principalmente se levarmos em consideração que assim como a Forma do belo "aparece" "subitamente" (exaíphnēs) (210e) ao erastếs depois de um longo esforço, do mesmo modo Alcibíades invade "subitamente" o sympósion de Agaton, na companhia de uma flautista e de um bando de foliões (212e). É ainda "subitamente" que Sócrates "aparece" ao lado de Agaton quando Alcibíades se dá por si no momento de coroar o tragediógrafo (213c); e por fim, é também "subitamente" que a estrutura ordenada do sympósion, já ameaçada com a entrada de Alcibíades, finalmente colapsa com a chegada de mais foliões.

Notemos que Platão utiliza a mesma palavra para descrever eventos radicalmente opostos como a "revelação" da Forma da beleza e o aparecimento da própria beleza na forma física de um homem. Mais do que um capricho linguístico, acredito que o advérbio marca precisamente um contraste, uma mudança de atmosfera, como se estivéssemos sendo levados de uma ordem da realidade a outra completamente diversa. Estas ordens distintas, afinal, são passíveis de serem captadas e compreendidas pelo mesmo sujeito? Esta é a pergunta para a qual deve-setentar encontrar uma resposta. Nussbaum (2009, p. 162), por exemplo, se fez este mesmo tipo de questionamento. Diante da constatação de que duas coisas a princípio tão dessemelhantes como o belo em si e um indivíduo possuem o mesmo modo de "aparecimento" e podem igualmente chamar nossa atenção, ainda que por meios distintos, Nussbaum se pergunta se com isso não seríamos "então levados a imaginar se há um tipo de entendimento em si mesmo vulnerável e dirigido a objetos vulneráveis - e, se houver, se a ascese o compreende, o transcende, ou simplesmente o ignora". Que estes objetos "vulneráveis" não são deixados para trás durante a ascese, procurei demonstrar há pouco. No entanto, gostaria de ir além e, ao invés de indagar se o intelecto (noûs) é capaz de produzir um entendimento destes objetos, perguntarei a respeito da possibilidade de que o amante realmente perfaça a ascese. Minha hi- 
pótese é de que o caráter subitâneo do aparecimento da Forma constitui um indicativo de que o "intercurso" com belo em si é algo que permanece além das capacidades humanas. Além disso, entendo que aquilo que Diotima descreve e prescreve como sendo o fim da scala amoris é incompatível com a definição da atividade filosófica como algo de intermediário entre a sabedoria e a ignorância, uma vez que, segundo a própria sacerdotisa, "nenhum deus filosofa ou deseja ser sábio - pois já é -, assim se alguém mais é sábio, não filosofa" (240a).

Recentemente tem-se procurado questionar a ideia de que a doutrina de Diotima constitua um projeto erótico-filosófico realizável para seres humanos. A partir do cotejamento das premissas avançadas nos primeiros "mistérios" com o que é prescrito na télea kai epoptiká, Gonzalez (2011, p. 54-61) reconhece, por exemplo, a incompatibilidade entre o modo como Diotima descreve a natureza filosófica de Erōs e a possibilidade de que se atinja o télos da ascese. Além de defender que tanto o ato de "conhecer" a beleza (210d) quanto o "intercurso" com o belo em si (212a) e a geração da verdadeira virtude deveriam ser encarados como formas de aquisição da sabedoria, o que por si só já seria suficiente para que se constatasse a dificuldade de se conciliar as duas partes do elogio de Diotima, este intérprete também admite que a linguagem utilizada pela sacerdotisa - o amante "se deita ao lado" da Forma; ele mantém "intercurso" com ela - aponta para uma experiência disruptiva, religiosa até, que jaz além do próprio ato de conhecer.

Especificamente no que concerne à última etapa da iniciação de Diotima, acredito que o diagnóstico feito por Gonzalez é correto $^{20}$. Ademais, note-se ainda que até este momento derradeiro a ascese vinha sendo marcada por um caráter essencialmente discursivo, caráter que parece ser abandonado com o "aparecimento" da Forma da beleza; Diotima inclusive é explicita a este respeito quando afirma que o belo em si não aparecerá ao amante como discurso, nem como conhecimento (oudé tis logos oudé tis epistémēe) (211a).

$20 \quad$ Quanto ao conhecimento da beleza, penúltima etapa da ascese, penso que há um modo de reconciliá-la com a caracterização da natureza filosófica de Erōs. Voltarei a este ponto a seguir. 
De todo modo, contra a hipótese aqui aduzida de que uma possível aquisição da sabedoria (alcançada por meio do intercurso com a Forma) constituiria um interdito ao filósofo, poder-se-ia sugerir que Erōs não toma parte na contemplação final, que só o intelecto (noûs) o faz ${ }^{21}$, o que manteria intacta a sua caracterização enquanto um metaxý. No entanto, as premissas defendidas por Sócrates na refutação das teses de Agaton são explícitas quando afirmam que se deseja apenas aquilo que de que se é carente; se há possessão não há desejo, uma vez que não se deseja aquilo que já se tem. No entanto, se quisermos fazer justiça à letra do Banquete, teremos que admitir que a respeito da presença (ou não) efetiva do desejo na contemplação final, Diotima, na verdade, se cala. No entanto, contra isto ${ }^{22}$, poder-se-ia ainda sustentar - ainda com Diotima - que permanece aberta a possibilidade de se desejar algo que já se possui; a diferença aqui é que este desejo tornar-se-á um desejo pela manutenção desse objeto no futuro (200c-d). Consequentemente, seria lícito supor que mesmo que o amante estivesse de posse do belo em si, haveria ainda um desejo, o desejo de possui-lo sempre. Por outro lado, caso se opte por não recorrer a este tipo de argumento, lembro mais uma vez que no mito do nascimento de Erōs nos é dito que nenhum dos estados - de aporía e de euporía - que compõe a sua natureza duram suficientemente a ponto de que um prevaleça sobre o outro (203e), de modo que poder-se-ia inferir que qualquer tipo de possessão, independentemente do objeto é, ela mesma, tempo-

21 É o caso, por exemplo, de H. Vaz (2012, p. 184-6), para quem "Éros aparece como desejo do belo e como 'intermediário' entre a privação do belo e sua posse. Quando, porém, a alma atinge o belo - na posse intelectual do Belo absoluto -, cessa a 'função mediadora' do amor, e Platão não fala sobre o amor no ato mesmo do conhecimento". Ou ainda quando afirma que "o amor do Belo é amor da ciência do Belo. Mas, obtida enfim a ciência, cessa o desejo; o Amor como 'filosofia', como desejo da ciência cessa como que no limiar da própria ciência".

22 Bury (1909, p. xlvi) de modo muito breve (e sem dar explicações de como isto ocorre) sugere que o desejo continua a desempenhar papel importante mesmo nos estágios finais da ascese, com a diferença que ali o $E r s$ que estaria em ação seria o Erōs do intelecto, do noûs. Todavia, acredito que a interpretação de Bury não encontra respaldo textual. Contudo, é plenamente possível explicar a possibilidade de se desejar algo que já se possui sem necessidade alguma de recorrer a um Erōs próprio do noûs, como 200b-d deixa claro. 
rária, daí não se poder sustentar que os estágios que compõem a scala amoris são estágios estacionários.

Sobre este último ponto é esclarecedora a leitura feita por Blondell (2006, p.147-179), para quem há no Banquete evidências suficientes para se crer que Sócrates, o amante paradigmático, pode tanto ocupar todos os estágios da scala amoris assim como nenhum. Sua ideia é de que devemos tomar Sócrates como que oscilando de cima a baixo na ascese; ademais, esta interpretação é atrativa pelos seguintes motivos: em primeiro lugar, ela mantém intacta a caracterização de Erōs enquanto daîmon, elemento mediador entre o humano e o divino, vacilando entre estados de aporía e euporia. Em segundo lugar, parece improvável, até mesmo impossível para um ser humano, pelo menos de um ponto de vista puramente empírico, manter-se permanentemente no topo da scala amoris. De minha parte, parece-me plausível supor que esta impossibilidade seria causada pela natureza subitânea do aparecimento do belo em si. O contato com algo tão radicalmente distinto de tudo aquilo que lhe antecede poderia ser, aos olhos do erastếs, algo tão extraordinário que a própria intensidade da visão, ao invés de lhe nutrir de esclarecimento, acabaria por ofuscar a sua vista ${ }^{23}$.

Diante das dificuldades elencadas até aqui, devemos finalmente nos perguntar: se o "intercurso" com a Forma permanece um interdito ao filósofo, qual seria então o limite alcançável a um ser humano na ascese de Diotima? A partir das evidências coligidas até aqui, acredito que este limite convirja com o momento em que o amante torna sua visão ao vasto "oceano" do belo, produz discursos em seu inesgotável amor ao saber e contempla uma ciência única que tem como objeto a beleza (210de), não apenas porque, como já indiquei há pouco, Diotima é explícita ao afirmar que é nesta etapa que o amante gera filosofia, mas também porque a própria sacerdotisa parece pôr em dúvida ${ }_{23} \quad$ É o que a visão permanente da beleza poderia acarretar de acordo com Blondell (200, p. 175): "o olhar do amante em toda a sua intensidade não pode permanecer nos corpos humanos, nas almas, nas atividades, e na Forma da Beleza, ao mesmo tempo. Ele não pode simultaneamente participar do mundo da comida e da bebida, e contemplar uma visão tão bela que o priva de qualquer desejo de fazê-lo (211d-e). Tal Beleza certamente irá cegar o amante completamente para a beleza deste mundo, do mesmo modo que a visão da Forma do Bem cega o filósofo que retorna à caverna na República". 
a capacidade de um filósofo como Sócrates de acompanha-la até o termo de seu ensinamento, qual seja, a contemplação da Forma da beleza e a geração da verdadeira virtude advinda do "intercurso" com o belo em si. Além de 209e-210a, passagem em que Diotima demonstra ceticismo em relação à possibilidade de que Sócrates fosse até mesmo iniciado nos "mistérios" finais, em 210 e - momento imediatamente posterior à visão do "oceano" do belo e do conhecimento da beleza -, temos outro indicativo da posição reticente assumida pela sacerdotisa, porquanto pede a Sócrates que "tente prestar-lhe a máxima atenção possível" e se esforce para manter-se focado em seu ensinamento. Estas passagens parecem indicar que a ascese não é um tipo de experiência que pode ser levada a cabo de modo pacífico. Além disso, mesmo que Diotima afirme que o amante "robustecido e crescido" pode então "contemplar uma ciência única, tal qual o seu objeto é o belo" (210e), ainda assim, não penso que podemos extrair daí qualquer evidência definitiva de que que se trata aqui de uma "ciência" em sentido forte - o que também preserva a caracterização de Erōs como um intermediário entre a sabedoria e a ignorância -, principalmente porque Diotima é clara quando afirma que esta etapa ainda não constitui o télos da scala amoris.

Ao sustentar, por exemplo, que o "conhecimento" da beleza que se segue à visão do "oceano" do belo constitui um estágio distinto daquele do "intercurso" do amante com a Forma, Blondell (2006, p. 174) sugere que esta diferença se explica em termos de uma distinção no tipo de captação envolvida na atividade intelectual do amante em cada uma destas duas etapas: enquanto na fase do "conhecimento" o erastếs teria apenas um "vislumbre" da unidade da beleza, na da "contemplação", por outro lado, haveria um "contato" mais duradouro com a Forma, e é somente através deste que a verdadeira virtude seria gerada $(212 a)^{24}$. Dado o modo de atividade epistêmica aqui em jogo,

Ainda que Blondell não se proponha a desenvolver este ponto, retomo a senda por ela aberta e sintetizo a questão nos seguintes termos: ainda que na penúltima etapa o amante consiga "vislumbrar" a unidade da beleza, faltaria ainda aquilo que no Mênon (98a) é descrito como um "cálculo de causa", i.e., algo que garantiria estabilidade ao conhecimento adquirido. Deste modo, o amante reconheceria a unidade da beleza sem, contudo, conseguir remeter ainda esta unidade à própria Forma, dada a subtaneidade do aparecimento da mesma. 
o que se apresenta a nós como "ciência" deveria ser entendido, segundo Blondell, antes como uma "opinião", devido ao caráter não duradouro da visão, do que como um conhecimento propriamente dito, estável e infalível. Quanto a isto, Blondell nos lembra ainda que é significativo que em 175e Sócrates afirme que a sua sabedoria, ao contrário da de Agaton que reluz e é desenvolvida, é um tanto ordinária, ou mesmo duvidosa como um sonho, o que parece corroborar a hipótese de que o tipo "conhecimento" que é próprio ao filósofo, no contexto da ascese, não pode ser entendido num sentido forte. Que esta, aliás, parece ser a leitura mais razoável, depreendemos mais uma vez da primeira parte do ensinamento de Diotima. Em 202a - passagem curiosamente negligenciada por Blondell em sua interpretação, mas que a meu ver constitui a principal evidência em favor da tese de que o que é alcançado pelo amante no penúltimo degrau da ascese não é uma ciência in strito sensu -, Diotima tenta convencer Sócrates de que há todo um reino de intermediários entre os extremos. A sacerdotisa então insiste junto a Sócrates para que este perceba que existe algo entre (ti metaxý) a sabedoria e a ignorância:

'o opinar certo, mesmo sem poder dar razão, não sabes', dizia-me ela, 'que nem é saber - pois o que é sem razão, como seria ciência? - nem é ignorância - pois o que atinge o ser, como seria ignorância? - e que é sem dúvida alguma coisa desse tipo a opinião certa, um intermediário entre entendimento e ignorância' (202a) ${ }^{25}$.

Ora, a passagem acima parece dizer mais do que se costuma supor; o que Diotima parece estar fazendo aqui, na verdade, é delimitar a própria área de atuação de Erōs enquanto um metaxý, e quando voltamos nossa atenção à ascese, seu movimento de demarcação parece agora plenamente justificável, isto porque se a sabedoria é apanágio dos deuses e a ignorância é marca daqueles que não reconhecem a si próprios como deficientes, Erōs, como philósophos, atua entre uma e outra num espaço intermédio que, segundo a própria Diotima, é ocupado pela opinião correta.

Contudo, ainda que o ensinamento de Diotima se apresente como irrealizável em sua plenitude, não acredito que

25 Sobre a distinção entre "opinião certa" e "ciência", vide Mênon (96d-98c). 
devemos tomar esta limitação como algo que frustra todo o esforço do amante. Ao contrário, penso que podemos extrair daí um quadro mais positivo em que a impossibilidade de se completar a ascese é o que faz, na verdade, com que o amante queira percorrê-la novamente, sempre que necessário. Lembremos que no mito de Aristófanes era Erōs, ali tomado como desejo de completude, quem alimentava as esperanças mais caras dos seres primordiais, enquanto estes ansiavam por tornarem-se perfeitos mais uma vez (193d). Diotima, nesta perspectiva, ofereceria a mesma promessa, reconciliar-se novamente com o que é perfeito, e o mesmo guia, Erōs. O dinamismo não é, portanto, marca distintiva somente de Erōs, mas da própria vida que se pretenda ser vivida filosoficamente. O que aparece, portanto, como uma deficiência - a impossibilidade de tornar-se sábio - na verdade, deve ser entendido como aquilo que nos faz efetivamente humanos e marca a atividade filosófica e a construção da vida virtuosa como um work in progress permanente. É somente quando reconhecemos nossas limitações que nos é possível buscar algo que nos faça querer superá-las. Como isto é possível? Através da geração e criação no belo. A causa, insiste Diotima, pela qual tanto seres humanos quanto animais põem-se a amar é que desejam que o bem torne-se seu sempre. Esta condição de precariedade e insegurança acaba por refletir-se em nossa própria constituição, entendida dinamicamente, tanto no que diz respeito ao corpo quanto à alma: cremos que da infância até a velhice um indivíduo permanece o "mesmo", quando na verdade suas características físicas jamais mantêm-se idênticas. O que ocorre na alma não é menos diferente do que ocorre com o corpo:

e não é que é só no corpo, mas também na alma os modos, os costumes, as opiniões, desejos, prazeres, aflições, temores, cada um desses afetos jamais permanece o mesmo em cada um de nós, mas uns nascem, outros morrem. Mas ainda mais estranho do que isso é que até as ciências não é só que umas nascem e outras morrem para nós, e jamais somos os mesmos nas ciências, mas ainda cada uma delas sofre a mesma contingência. O que, com efeito, se chama exercitar (meletân) é como se de nós estivesse saindo a ciência (epistémēs); esquecimento (lethē) é escape de ciência, e o exercício, introduzindo uma nova lembrança em lugar da que está saindo, salva a ciência, de modo a parecer ela ser a mesma. 
O que é marcante na concepção de Diotima é que o conhecimento, assim como acontece com o corpo, submete-se à mesma espécie de dinamismo, o que implica um cuidado constante e permanente para que retenhamos o que quer que seja, uma vez que tudo nos escapa. Erōs atua assim como a força capaz de salvar nossos conhecimentos do esquecimento e trazê-los à vida por meio da recordação. Quanto a isto, parece-me de todo modo estranho supor que a natureza de nossos conhecimentos explicitada em 207d-e - essencialmente mortal, deve-se reconhecer, pois pautado pela carência e que supõe, para a sua manutenção, uma espécie de produção ou geração -, quando no momento da ascese dialética, venham a assumir uma outra significação. Se, como venho insistindo até aqui, aquilo que Diotima descreve na primeira parte do seu elogio continua sendo válido, em suas linhas gerais, nos "mistérios" finais, não deveríamos então admitir que a própria noção de um conhecimento sujeito à oscilação, que seja naturalmente instável, parece incompatível com aquilo que se costuma tomar como conhecimento, no sentido forte do temo, um processo de captação cujo objeto são as Formas platônicas, entidades "perfeitas", "eternas" e "imutáveis" (210a-d) ${ }^{26}$ ? Como reconciliar duas coisas que, à primeira vista, parecem irreconciliáveis?

Venho defendendo até aqui que o tipo de atividade psíquica (neste caso específico, cognitiva) que Diotima descreve como sendo própria aos seres humanos é inadequada à captação plena das Formas. Agora admito inclusive que a causa desta incompatibilidade provém também da própria concepção de psykhé adotada pela sacerdotisa. Muitos notaram que em sua argumentação Diotima recorre a uma caracterização não-substancial (heraclítica) da alma ${ }^{27}$. As implicações desta caracterização, principalmente se levarmos em consideração a função que a alma assume enquanto "sujeito cognitivo" na filosofia platônica, comprometem em grande medida a atribuição a Diotima de uma doutrina epistemológica que satisfaça as exigências que vemos ser feitas em outros diálogos, especialmente

\footnotetext{
$26 \quad$ Vide Timeu (29b-c); República (474d-480a, 509e-510a).

27 Compartem dessa ideia Calvacante de Souza (2016, p. 230), R. E. Allen (1991, p. 75) e Hyland (2005, p. 52), por exemplo.
} 
naquelas em que a doutrina da reminiscência (anámnēsis) se faz presente, como o Mênon (81b-84a), o Fédon (72e-77a) e o Fedro (249b-d).

Sem entrar em detalhes a respeito das particularidades que esta doutrina assume em cada um destes diálogos, é possível, entretanto, assegurar que o conhecimento do inteligível mediante a anámnēsis supõe necessariamente que a alma: a) seja imortal; b) que se conserve idêntica a si própria; c) que mantenha com as Formas inteligíveis uma relação de semelhança; d) que mova a si mesma. Ora, tão logo nos deparamos com estas exigências podemos reconhecer sua ausência na descrição da psykhé efetuada por Diotima.

Dentre todos estes requisitos que citei há pouco e sua presença ou não no Banquete, o da "alma imortal" foi o que sem dúvida alguma mais mobilizou intérpretes em busca de uma solução, principalmente pelo vínculo estabelecido noutros diálogos entre a contemplação das Formas e a imortalidade da psykhé. É exatamente com base neste vínculo, por exemplo, que Bury (1909, p. xliii-xlv) argumentava em favor da presença de uma imortalidade individual no Banquete, adquirida mediante o contato com o objeto da contemplação que é, ele próprio, imortal. De acordo com Bury, se nos mantivermos atentos à diferença estabelecida por Diotima entre o ser humano entendido enquanto ánthrōpos de um lado, sempre sujeito aos efeitos do tempo, e noêtikòs ou lógikos de outro, então a reconciliação entre o Banquete e os demais diálogos platônicos que sustentam a imortalidade da alma individual torna-se possível ${ }^{28}$. Luce (1952, p. 137-141) defendeu um ponto de vista semelhante ao de Bury. Segundo este intérprete, se o interesse de Diotima é descrever a alma a partir da sua inseparabilidade do corpo, então é natural que a ênfase de toda a sua descrição resida exatamente na valorização dos aspectos "mortais" que são próprios à natureza humana, ao contrário do que vemos ser defendido no Fédon. Na perspectiva de Luce estaríamos antes diante de dois modos dis$28 \quad$ Ainda que Bury (1909, p. xlv) adote uma postura confiante em relação à presença da imortalidade da alma individual no Banquete - sustentada principalmente a partir de uma leitura mais livre da cláusula eíper tōi allōi em 212a -, ele é sóbrio o bastante para afirmar que em nenhum momento esta imortalidade pessoal é diretamente provada ou afirmada; o que teríamos seria uma explicação da imortalidade apenas em termos de renome póstumo. 
tintos para se abordar um mesmo problema do que propriamente perante uma inconsistência: enquanto no Fédon a alma é tratada sob a perspectiva da morte, no Banquete, ao contrário, o horizonte adotado é o da vida. Ademais, partindo da admissão de que assim como podemos atribuir dois sentidos à psykhế, "vida" num sentido mais amplo e "alma" num mais específico, Luce defende a existência de dois tipos de imortalidade, uma no "tempo" e outra na "eternidade". A imortalidade no "tempo", sempre vicária, seria própria às almas encarnadas, enquanto a imortalidade na "eternidade" seria atingida através da separação do corpo.

Ainda que porventura possa-se dar razão a ambos os intérpretes em um ou noutro ponto, não me parece fortuito, contudo, que Diotima dispense à alma o tratamento que acaba por dispensar. Não creio que se trata simplesmente de uma questão de linguagem como sugere Bury, tampouco de uma questão de abordagem como defende Luce. Aliás, se há uma diferença na abordagem do problema da imortalidade da alma no Banquete - algo que aceito de bom grado - a tarefa de qualquer intérprete é tentar compreender o porquê disto, afinal. Minha hipótese é de que a imortalidade da alma permanece de fato um interdito no Banquete, que o único tipo de imortalidade concedido ao ser mortal é através da reprodução, e que o objetivo disso é marcar com precisão a diferença existente entre aquilo que é humano e o que concerne ao divino:

é desse modo [pela geração] que tudo o que é mortal se conserva, e não pelo fato de absolutamente ser sempre o mesmo, como o que é divino, mas pelo fato de deixar o que parte e envelhece um outro ser novo, tal qual ele mesmo era. É por esse meio, ó Sócrates, que o mortal participa da imortalidade, no corpo como em tudo o mais; o imortal porém é de outro modo.

Esta é uma tensão que, se ainda cabe insistir, permeia todo o elogio de Diotima. Ao negar a possibilidade de um ser humano tornar-se efetivamente imortal, Diotima parece tornar infactível a própria assimilação ao divino (homoiōsis theōi).

Diante disso, não precisamos supor, por exemplo, que no Banquete Platão tenha enfrentado uma crise de ceticismo em relação à imortalidade da alma ${ }^{29}$. Ao contrário, defendo que todo $29 \quad$ É o caso, por exemplo, de Hackforth (1950, p. 43-5). 
o argumento com respeito à imortalidade no discurso de Diotima serve a um propósito determinado, qual seja, estabelecer um limite às nossas capacidades e marcar assim nossa diferença com relação ao divino. Neste sentido, a própria possibilidade de que se contemple as Formas e que se complete a ascese, nesta perspectiva, permanece uma incerteza, uma vez que nos falta uma composição psíquica adequada para tal. Eis porque questiono a hipótese de que de acordo com o ensinamento de Diotima é possível tornar-se sábio (sabedoria aqui entendida enquanto uma posse permanente do objeto inteligível). A limitação aparece, portanto, como marca da nossa própria mortalidade.

\section{Conclusão}

O que Diotima pode, enfim, nos ensinar com sua sabedoria religiosa? Que o télos da scala amoris, mesmo que inalcançável, pode nos servir ao menos como um "ideal", lembrando-nos a todo instante o modo como a vida deveria ser vivida ${ }^{30}$. Tal como no mito contado por Aristófanes, onde Apolo deliberadamente deixa aberta algumas das feridas dos seres huma-

30 A posição de Kant quanto ao ideal da sabedoria é esclarecedora e se adequa bem, guardadas as devidas proporções, ao que vemos ser sustentado por Diotima no Banquete: "embora não indo tão longe, temos de confessar que a razão humana contém não só ideias, mas também ideais que, embora não possuam força criadora como os de Platão, tem no entanto força prática (como princípios reguladores) e sobre eles se funda a possibilidade de perfeição de certas ações. Os conceitos morais não são inteiramente conceitos puros da razão, porque assentam sobre algo empírico (prazer ou desprazer); todavia em relação ao princípio pelo qual a razão põe limites à liberdade, que é em si destituída de leis (quando se atende unicamente à sua forma), podem muito bem servir de exemplo de conceitos puros da razão. A virtude, e com ela a sageza humana, em toda a sua pureza, são ideias. Mas os sages (do estóico) é um ideal, isto é, um homem que só no pensamento existe, mas que coincide inteiramente com a ideia de sageza. Assim como a ideia dá a regra, assim o ideal, nesse caso, serve de protótipo para a determinação completa da cópia e não temos outra medida de nossas ações que não seja o comportamento deste homem divino em nós, com o qual nos comparamos, nos julgamos e assim nos aperfeiçoamos, embora nunca o possamos alcançar. Conquanto não queiramos atribuir realidade objetiva (existência) a estas ideias, nem por isso devemos considera-los quiméricos, porque concedem uma norma imprescindível à razão, que necessita do conceito do que é inteiramente perfeito na sua espécie para por ele avaliar e medir o grau e os defeitos do que é imperfeito" (CRP, B597-8). 
nos recém-seccionados justamente para que não se esqueçam do seu antigo estado, bem como da hýbris em que incorreram (191a), o ensinamento de Diotima, do mesmo modo, não nos deixa esquecer que ainda que desejemos a todo custo ultrapassar nossa mortalidade, a transcendência que almejamos será sempre marcada por certa deficiência. Os elogios de Aristófanes e Diotima compartilham assim do mesmo tom trágico: se no primeiro caso a tentativa de equiparar-se ao divino gerou a ruína dos seres primordiais até então autossuficientes, e o que agora lhes resta é tentar remediar as dores que lhe acometem desde então, com Diotima aprendemos que mesmo que não consigamos nos equiparar aos deuses, podemos ainda remediar nossas deficiências de outro modo: filosofando. É este, a meu ver, o sentido da afirmação de Sócrates no início do Banquete, quando admite nada mais saber a não ser a tà erotiká (177d). A positividade da afirmação continua sendo, na verdade, radicalmente negativa: o único conhecimento que o filósofo efetivamente possui é o conhecimento dos seus próprios limites, de até onde pode chegar e o que precisa fazer para atingir este fim, sempre ávido, tal qual Erōs, em busca do belo e do bem ${ }^{31}$.

\section{Referências}

ALLEN, R. E. The dialogues of Plato. Vol. 2: The Symposium. New Haven: Yale University Press, 1991.

BLONDELL, R. Where is Socrates in the "Ladder of Love"?.In:

LESHER, J.; NAILS, D.; SHEFFIELD, F. Plato's Symposium. Issues in Interpretation and Reception. Washington, D.C.: Center for Hellenic Studies, 2006, p. 147-178.

BURY, R.G. The Symposium of Plato. With introduction, critical notes and commentary. London: Simpkin, Marshall and Co., 1909.

CHEN, L. Knowledge of Beauty in Plato's Symposium. The Classical Quarterly (New Series), Cambridge, UK, v. 33, n. 1, p. 66-74, 1983.

DOVER, K. A homossexualidade na Grécia Antiga. Tradução de Luís S. Krausz. São Paulo: Nova Alexandria, 1994.

$31 \quad$ Agradeço especialmente a um dos avaliadores anônimos da Princípios pelas sugestões e pelas críticas pertinentes endereçadas a algumas partes deste artigo. Graças a elas pude reformular certos pontos da minha argumentação e, com isso, espero ter tornado minha interpretação da scala amoris do Banquete mais convincente. 
FERRARI, G. R. F. Platonic Love. In: KRAUT, R. Cambridge Companion to Plato. Cambridge: Cambridge University Press, 1992. p. 248-276.

GONZALEZ, F. "All of sudden": discontinuites and the limits of philosophy in Plato's Symposium. Perspectiva Filosófica. Pernambuco, PB, v. 2, no 36 , p. 43-69, 2011.

HACKFORTH, R. Immortality in Plato's Symposium. The Classical Review, vol. 64, n 2, p. 43-45, 1950.

HALPERIN, D. Platonic Erôs and What Men Call Love: Ancient Philosophy, v. 5, $\mathrm{n}^{\circ}$ 2, p. 161-204, 1985.

HYLAND, D. The question of beauty in Plato. Bloomington: Indiana University Press, 2008.

KANT, I. Crítica da Razão Pura. Tradução de Manuela Pinto dos Santos e Alexandre Fradique Morujão. $5^{\mathrm{a}}$ ed. Lisboa: Fundação Calouste Gulbekian.

LUCE, V. Immortality in Plato's Symposium: A Reply. The Classical Review, new series, vol. 2, no 3/4, p. 137-141, 1952.

MORAVCSIK, J. M. E. Reason and Eros in the "Ascent"-Passage of the Symposium. In: ANTON, J. P.; KUSTAS, G. Essays in Ancient Greek Philosophy. Albany: State University of New York Press, 1971.

NEHAMAS, A. Beauty of Body, Nobility of Soul: The pursuit of love in Plato's Symposium. In: SCOTT, D. (Org.) Maieusis: essays in Ancient Philosophy in honour of Miles Burnyeat. New York: Oxford University Press, 2007.

NIGHTINGALE, A. E. The Folly of Praise: Plato's Critique of Encomiastic Discourse in the Lysis and Symposium. The Classical Quaterly (New Series). Vol. 43, no 1, p. 112-130, 1993.

NUSSBAUM, M. A fragilidade da bondade: fortuna e ética na tragédia e na filosofia grega. Tradução de Ana Aguiar Cotrim. São Paulo: WMF Martins Fontes, 2009.

PLATÃO. A República. Introdução, tradução e notas de Maria Helena da Rocha Pereira. $5^{\mathrm{a}}$ ed. Lisboa: Fundaçã̃o Calouste Gulbenkian.

PLATÃO. Critão, Menão, Hípias Maior e outros. Tradução de Carlos Alberto Nunes. $2^{\mathrm{a}}$ ed. Belém: EDUFPA, 2007.

PLATÃO. Fedro. Tradução e apresentação de José Cavalcante de Souza; posfácio e notas de José Trindade Santos. São Paulo: Editora 34, 2016.

PLATÃO. O Banquete. Tradução, posfácio e notas de José Cavalcante de Souza. São Paulo: Editora 34, 2016.

PLATÃO. Timeu - Crítias. Tradução do grego, introdução, notas e índices de Rodolfo Lopes. Coimbra: Centro de Estudos Clássicos e Humanísticos, 2011. 
PLATO. Symposium. Edited by Sir Kenneth Dover. Cambridge: Cambridge University Press, 1980.

PLATON. Le Banquet. Traduction inédite, introduction e notes par Luc Brisson. 5a édition. Paris: GF Flammarion, 2007.

SAFO DE LESBOS. Hino a Afrodite e outros poemas. Organização e tradução de Giuliana Ragusa. São Paulo: Hedra, 2011.

SCOTT, D. Socrates and Alcibiades in the "Symposium". Hermathena, no 168, p. 25-37, 2000.

SHEFFIELD, F. The Role of the Earlier Speeches in the Symposium: Plato's Endoxic Method?. In: LESHER, J.; NAILS, D.; SHEFFIELD, F. Plato's Symposium. Issues in Interpretation and Reception. Washington, D.C.: Center for Hellenic Studies, 2006a, p. 23-46.

SHEFFIELD, F. C. C. Plato's Symposium: The Ethics of Desire. Oxford: Claredon Press, 2006b.

VAZ, H. C. L. Contemplação e dialética nos diálogos platônicos. Tradução do latim para o português feita por Juvenal Savian Filho. São Paulo: Loyola, 2012.

VLASTOS, G. The individual as an object of love in Plato's Symposium. In: FINE, G. Plato 2: Ethics, Politics, Religion, and the Soul. Oxford: Oxford University Press, 1991, p. 137-163. 